\title{
Analysis of indole derivatives in methanolic extracts from mycelium of Agaricus bisporus cultured in vitro on liquid Oddoux medium
}

\author{
Bożena MuszyńsKa*, Katarzyna SuŁkowska-Ziaja, Patrycja HaŁaszCZuK, \\ REMIGIUSZ KRĘŻAŁEK \& MACIEJ ŁOJEWSKI \\ Department of Pharmaceutical Botany, Faculty of Pharmacy, Jagiellonian University Medical College, \\ Medyczna 9, 30-688 Kraków, Poland \\ E-mail: muchon@poczta.fm
}

\section{ABSTRACT}

Methanolic extracts obtained from biomass of Agaricus bisporus (J.E. Lange) Imbach cultured in vitro were analyzed for qualitative and quantitative composition of non-hallucinogenic indole compounds in order to compare their amount with fruiting bodies of these species. Extracts demonstrated to contain six indole compounds. Contents of individual compounds ranged from 0.01 to $21.33 \mathrm{mg} / 100 \mathrm{~g}$ d.w. in biomass from in vitro cultures. The quantitatively dominating compounds included: 5-hydroxytryptophan (12.50 mg/100 g d.w.), Ltryptophan (14.00 mg/100 g d.w.) and serotonin (7.00 mg/100 g d.w.). Total content of the remaining indole compounds under analysis in the study was $55.32 \mathrm{mg} / 100 \mathrm{~g}$ d.w.

KEY WORDS: Agaricus bisporus, in vitro culture, L-tryptophan, serotonin

\section{Introduction}

The project consisted of experiments utilizing edible mushroom: Agaricus bisporus - White bottom mushroom (Basidiomycota), mainly because this species is widely used for commercial purposes in Poland and Europe, and among all mushroom species, it is the most frequently consumed mushroom in Polish and European society due to its taste and nutritional qualities. In addition, choice of mushroom was influenced by practical aspects - a possibility for mass production. Currently, fruiting bodies of A. bisporus are irradiated by UV light during process of production to increase vitamin D content (Roberts 2008, Koyalamudi et al. 2008). Fruiting body of $A$. bisporus also contains ergothioneine compound. This substance plays an important antioxidative and antimutagenic role, as well as chemo- and radioprotective (Ey et al. 2007). A. bisporus is also a highly valued source of laccase, vitamins (especially riboflavin, vitamin D3) and bioelements such as selenium, magnesium, copper, iron, calcium, zinc and potassium (Baross et al. 2008, Roberts 2008, Reczyński et al. 2013). 
The group of indole compounds that are not yet fully researched belongs to non-hallucinogenic indole type. Taking into consideration the significance of such indole derivatives as Ltryptophan, 5-hydroxytryptophan, 5methyltryptamine, serotonin, melatonin, tryptamine - which are known as neurotransmitters or their precursors, it makes sense to examine the presence of them in edible mushrooms (Muszyńska et al. 2007, 2009, $2011 \mathrm{a}, \mathrm{b}, \mathrm{c}, 2012 \mathrm{a}, \mathrm{b}$ ). A notable aspect regarding mycelium of higher mushrooms is its ability to accumulate easily absorbed substances but there is a lack of information in

\section{Material and methods}

Fungal material

The studies were conducted with young fruiting bodies of Agaricus bisporus (White button mushroom) from commercial origin. After taxonomic identification based on Knudsen and Vesterholt (2008) (representative samples of mushrooms were deposited in

\section{In vitro culture}

The pieces of fruiting bodies were defatted with $70 \%$ ethanol for $15 \mathrm{~s}$ then sterilized in $15 \%$ hypochlorite solution for $5 \mathrm{~min}$ (manufactured by Unilever, Hungary). After several rinses with

\section{Experimental in vitro culture}

After growing on solid medium, the pieces of mycelium were placed into an Erlenmeyer flask $(500 \mathrm{~mL})$ containing $250 \mathrm{~mL}$ of liquid modified Oddoux medium at initial biomass of $0.1 \mathrm{~g}$. The cultures were incubated at the temperature $25 \pm 2^{\circ} \mathrm{C}$ under $16 \mathrm{~h}$ light (900 1x/8 dark) and shaken at $140 \mathrm{rpm}$ (shaker ALTEL, Łódź). The agitated liquid cultures of $A$. bisporus were maintained for two weeks and were subcultured afterwards. The obtained respects to types and degree of accumulation of such compounds introduced to culture media. Due to this, these mushrooms can be used for a research of indolic compounds accumulated in the biomass from in vitro cultures. The difficulty in obtaining research material (due to temporary and unpredicted occurrence of fruiting bodies from natural sites) were the reason to use biomass from in vitro cultures for further experiments (Muszyńska et al. 2012a, b). Morever, in enclosed laboratory conditions, it is easier to control accumulation of chosen metabolites.

the Department of Pharmaceutical Botany, Jagiellonian University Collegium Medicum, Kraków, Poland), some of young sporocarps were used to derive in vitro cultures, from which obtained mycelium formed material for further analysis.

sterile redistilled water, mycelium fragments were transferred to Petri dishes containing agar-solidified medium with composition according to Oddoux (1957).

biomass was separated from the liquid medium using Büchner funnel with a filter paper, rinsed with redistilled water and immediately dried by lyophilization (lyophilizer Freezone 4.5, Labconco; temperature: $-40^{\circ} \mathrm{C}$ ).

Dry, lyophilized materials (5 $\mathrm{g}$ of each species) were placed in a glass percolator and extracted with petroleum ether under dark conditions to remove oil fractions. Oil fractions were discarded and the remaining biomass was dried and 
extracted again with methanol in a percolator for $24 \mathrm{~h}$. The extracts were concentrated by distillation in a vacuum evaporator under reduced $(200 \mathrm{mBa})$ pressure at $40^{\circ} \mathrm{C}$. To remove the remaining lipids, concentrated extracts were frozen, while polysaccharides were removed using Chihara method. The residues were quantitatively dissolved in methanol, filtered through Whatman No. 3 paper and purified by TLC. For the purification of the extracts, we used TLC aluminium-backed silica gel 60 plates (Merck, Art. No 1.055540001), onto which the methanol extracts were loaded. Chromatograms were developed in mobile phase found to be optimal for separation of indole compounds: n-propanol/ethyl acetate/water (7:1:2 $\mathrm{v} / \mathrm{v} / \mathrm{v})$. Spots containing indole compounds were identified under a UV lamp at $\lambda=280 \mathrm{~nm}$. TLC chromatogram of extract from mycelium of $A$. bisporus is presentend in Fig. 1. The obtained fractions were extracted from chromatograms with methanol, filtered through syringe driven filter unit (Millex, Milipore Corporation, USA) than concentrated by distillation in a vacuum evaporator under reduced pressure at $40^{\circ}$ C. The extracts, quantitatively dissolved in $1.5 \mathrm{~mL}$ of methanol, were subjected to HPLC analysis.

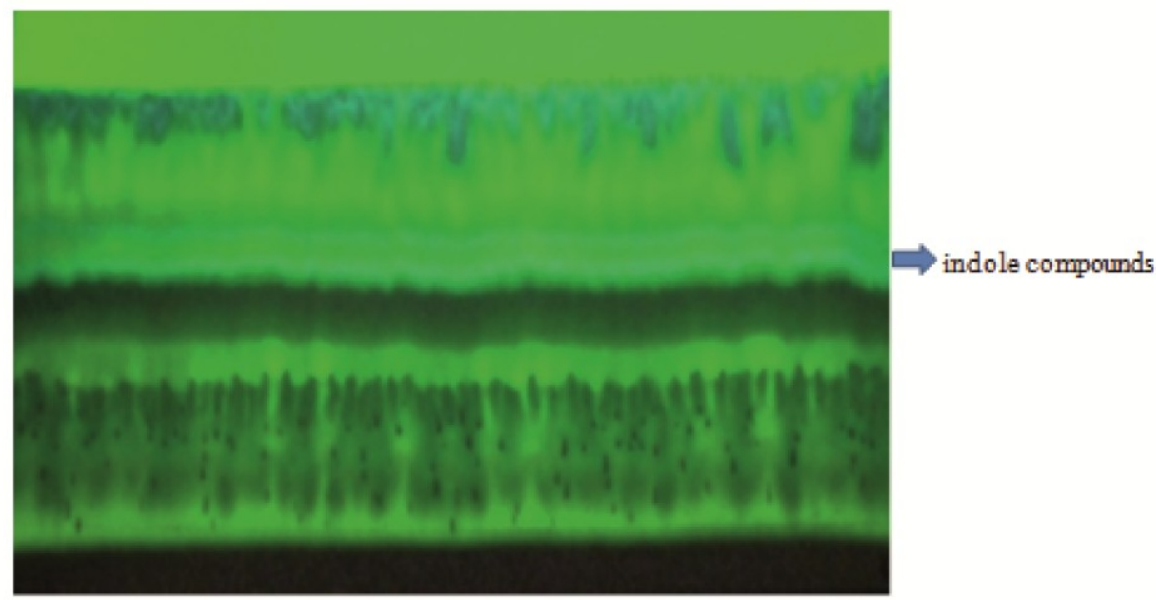

Figure 1. TLC chromatogram of extract from mycelium of Agaricus bisporus identified under a UV lamp at $\lambda=280 \mathrm{~nm}$.

\section{High performance liquid chromatography analysis (HPLC)}

The obtained extracts were analyzed for contents of L-tryptophan, 5hydroxytryptophan, 5-methyltryptamine, serotonin, melatonin, tryptamine, kynurenine sulfate, indoleacetic acid, indoleacetonitrile, indole and indoleacetamide. The analysis was performed according to the procedure by
Kysilka and Wurst (1985) with our modifications (Muszyńska et al. 2009). HPLC analyses were performed with Hitachi apparatus equipped with L-7100 pump, reversed phase column: Purospher® RP-18 (4 x 200 mm, $5 \mu \mathrm{m}$ ) at $25^{\circ} \mathrm{C}$. The solvent system used for analysis was composed of: 
methanol/water/ammonium acetate $(15: 14: 1 \mathrm{v} / \mathrm{v} / \mathrm{v})$ at flow rate of $1 \mathrm{ml} / \mathrm{min}$. Detection was carried out with a UV detector, using $\lambda=280 \mathrm{~nm}$. The identification of indole compounds was made by comparing the retention times of sample peaks with those of the standards. The presence of tested metabolites in the sample was evident as an increase in peak height for the appropriate retention time. Quantitative analysis was carried out using the calibration curve method. The results are expressed in $\mathrm{mg} / 100 \mathrm{~g}$ of dry weight, calculated by internal normalization of the chromatographic peak area. A representative chromatogram is presented in Figure 2.

For each mushroom, three samples were used for the determination of the quality attribute and all the analyses were carried out in triplicate. The results were expressed as the mean values and standard deviation (SD). The experimental data were submitted for analysis of variance for completely random design to determine the least significant difference at the level of 0.05 .

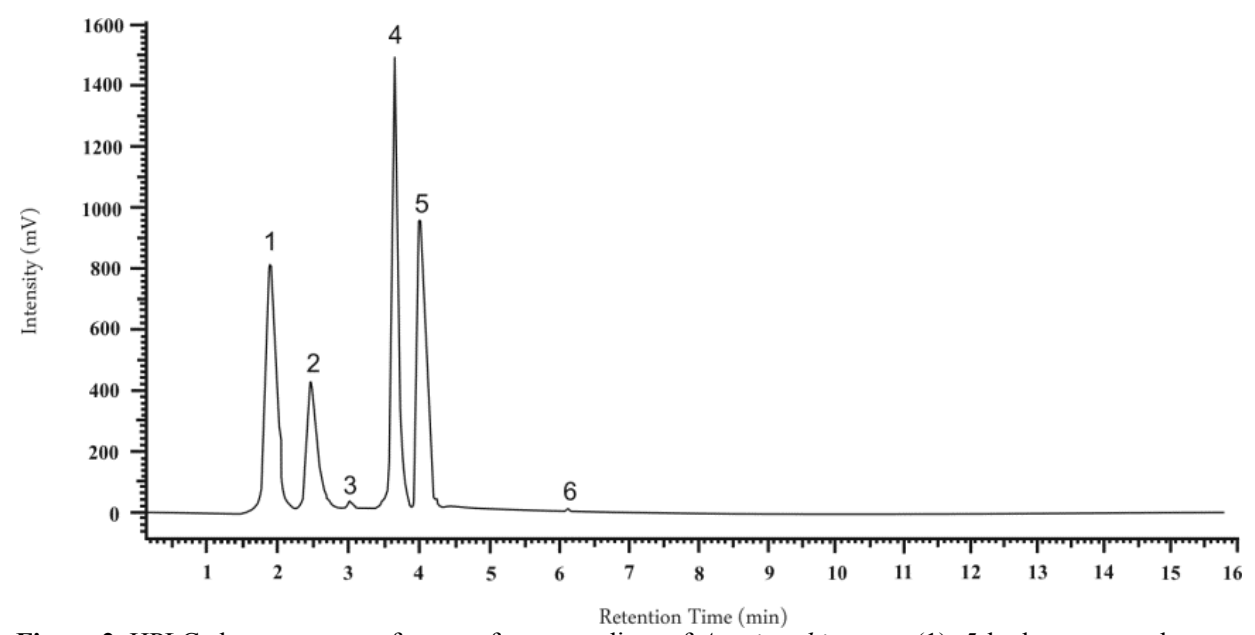

Figure 2. HPLC chromatogram of extract from mycelium of Agaricus bisporus: (1) -5-hydroxytryptophan, (2) - serotonin, (3) - tryptamine, (4) -5-methyltryptamine, (5) - L-tryptophan, (6) - melatonin.

\section{Results}

After several attempts to establish an optimal sterilization method, we were successful in the initiation of $A$. bisporus mycelia in vitro culture from hymenial part of fresh, young fruiting bodies. The best biomass growth was obtained during 3-week growth cycles in shaking liquid cultures using modified Oddoux medium. The biomass growth in the initiated cultures averaged at $8.1 \mathrm{~g}$ d.w./L of medium. Maximum mycelium biomass growth of $A$. bisporus was observed at initial medium $\mathrm{pH}$ of 6.2 and at temperature of $25^{\circ} \mathrm{C}$. In vitro cultures maintained under laboratory conditions and optimized for maximum growth, can provide a uniform mycelium which may be a reproducible and efficient source of metabolites. The obtained biomass increments and dynamics of mycelium growth did not differ from the results that we obtained for Boletus badius (Fr.) Kuhn. ex Gilb, Cantharellus cibarius Fr. and Tricholoma equestre (L.) Kumm. and for Calocera viscosa (Pers.) Fr. cultures studied earlier (Muszyńska et al. 
2009, 2011c, 2012b). The HPLC procedure applied to determine qualitative and quantitative content of non-hallucynogenic indole compounds offered an optimum conditions for most effective separation of the analyzed metabolites. Methanolic extracts obtained from biomass of $A$. bisporus cultured in vitro were analyzed for qualitative and quantitative composition of nonhallucinogenic indole compounds and their amount was compared with ones obtained from fruiting bodies of these species. The extracts were shown to contain six indole compounds: L-tryptophan, 5-hydroxytryptophan, serotonin, melatonin, tryptamine and 5methyltryptamine. Contents of individual compounds varied ranging from 0.01 to $21.33 \mathrm{mg} / 100 \mathrm{~g}$ d.w. in biomass from in vitro cultures. The quantitatively dominating compounds included: 5methyltryptamine (21.33 mg/100 g d.w.), L-tryptophan (14.00 mg/100 g d.w.), 5hydroxytryptophan $(12.50 \quad \mathrm{mg} / 100 \quad \mathrm{~g}$ d.w.) and serotonin $(7.00 \mathrm{mg} / 100 \mathrm{~g}$ d.w. $)$. The total content of the remaining indole compounds was $55.32 \mathrm{mg} / 100 \mathrm{~g}$ d.w. The contents of the remaining indoles: melatonin and tryptamine in mycelium from in vitro cultures were low, below $1.00 \mathrm{mg} / 100 \mathrm{~g}$ d.w. The contents of indole compounds in the methanolic extracts of mycelium of $A$. bisporus and in fruiting bodies are presented in Table 1.

Table 1. Contents of indole compounds under study ( $\mathrm{mg} / 100 \mathrm{~g} \mathrm{~d}$. w.) in extracts from mycelium and fruiting bodies of Agaricus bisporus. Data are presented as the mean \pm SE of 3 series.

\begin{tabular}{lcc}
\hline Indole compounds & $\begin{array}{c}\text { Agaricus bisporus } \\
\text { mycelium from cultures } \\
\text { in vitro }(\mathrm{mg} / 100 \mathrm{~g} \mathrm{d.w.})\end{array}$ & $\begin{array}{c}\text { Agaricus bisporus } \\
\text { fruiting bodies } \\
(\mathrm{mg} / 100 \mathrm{~g} \mathrm{d.w} .)\end{array}$ \\
\hline $\begin{array}{l}\text { L-tryptophan } \\
\text { 5-Hydroxytryptophan }\end{array}$ & $14.00+/-0.300$ & $0.39+/-0.003$ \\
Serotonin & $12.50+/-0.671$ & $5.21+/-0.055$ \\
Melatonin & $7.00+/-0.070$ & $0.11+/-0.006$ \\
Tryptamine & $0.01+/-0.006$ & $0.02+/-0.002$ \\
Indole-3-acetic acid & $0.48+/-0.050$ & $0.19+/-0.017$ \\
5-Methyltryptamine & $\mathrm{a}$ & $\mathrm{a}$ \\
\hline
\end{tabular}

a - Content lower than $0.001 \mathrm{mg} / 100 \mathrm{~g} \mathrm{~d}$. w.

\section{Discussion}

The fruiting bodies of $A$. bisporus indicated presence of five indolic compounds: melatonin, tryptamine, Ltryptophan, serotonin, indolo-3-acetic acid (contents from 0.06 to $5.21 \mathrm{mg} / 100$ g d.w.). Serotonin was quantitatively dominant compounds in extracts from fruiting bodies of this species (5.21 $\mathrm{mg} / 100 \mathrm{~g}$ d.w.) (Muszyńska et al. 2011a). However, the mycelium from in vitro cultures showed a greater content of these indolic compounds. Serotonin contents were of the same order of magnitude but were slightly greater in the extracts from in vitro culture (7.00 $\mathrm{mg} / 100 \mathrm{~g}$ d.w.). On the other hand, Ltryptophan contents were almost 30 times greater in the material from in vitro cultures compared with the fruiting bodies (14.00 and $0.39 \mathrm{mg} / 100 \mathrm{~g}$ d.w., 
respectively). In addition, extracts from in vitro cultures were characterized by the presence of 5-hydroxytryptophan and 5-methyltryptamine but the absence of indole-3-acetic acid evidenced in the fruiting bodies. To the best of our knowledge, this is the first time to identify and quantify indole compounds from in vitro culture of $A$. bisporus, the most popular edible mushroom. The mycelial culture seems to be a valid model for investigation of indole compounds accumulation and to study their metabolism in mushrooms. High content of serotonin and its precursors L-tryptophan and 5hydroxytryptophan in the fruiting bodies and in the mycelium cultured in vitro of A. bisporus, demonstrate also a potential

\section{References}

Barros, L., Cruz, T., Baptista, P., Estevinho, L.M. \& Ferreira, I. 2008. Wild and commercial mushrooms as source of nutrients and nutraceuticals. Food Chemistry and Toxicology, 46: 2742-2747.

Ey, J., Schömi, E. \& Taubert, D. 2007. Dietary sources and antioxidant effects of ergothioneine. Journal of Agricultural and Food Chemistry, 55: 6466-6474.

Knudsen, H. \& Vesterholt, J. 2008. Funga Nordica: agaricoid, boletoid and cyphelloid genera. Copenhagen, Nordsvamp.

Koyalamudi, S.R., Jeong, S.C., Song, C.H., Cho, K.Y. \& Pang, G. 2008. Vitamin $\mathrm{D}_{2}$ formation and bioavailability from Agaricus bisporus button mushrooms treated with ultraviolet irradiation. Journal of Agriculture and Food Chemistry, 57: 3351-3355.

Kysilka, R. \& Wurst, M. 1985. High performance liquid chromatographic determination of hallucinogenic indoleamins with simultaneous UV photometric and voltametric detection. Journal of Chromatography, 320: 414-420.

Muszyńska, B. \& Sułkowska-Ziaja, K. 2012a. Analysis of indole compounds in edible Basidiomycota species after thermal processing. Food Chemistry, 132: 455-459.

Muszyńska, B. \& Sułkowska-Ziaja, K. 2012 b. Analysis of indole compounds in fruiting bodies and in mycelia from in vitro cultures of Calocera viscosa (Basidiomycota). Acta Mycologica, 47: 57-64. for the use of this material as a source of this physiologically important compound for humans. Serotonin is a long known compound playing the role of a regulator of sleep, body temperature, mood, maturation and regeneration and an inhibitor of cell aging, thereby contributing to general strengthening of the immune system and is used also as an antidepressant. Further optimization of conditions for in vitro cultures may allowan alternative method for commercial cultivation of this species. This is desirable since it may be expected that mycelium cultured in vitro may also be a source of other important metabolites, possessing both culinary and medicinal values, characteristic of fruiting bodies.

Muszyńska, B., Maślanka, A., Sułkowska-Ziaja, K. \& Krzek, J. 2007. Analysis of indole compounds and nitric bases in fruiting bodies in Lactarius deterrimus by TLC-UV. Journal of Planar Chromatography Modern TLC, 20: 55-58.

Muszyńska, B., Sułkowska-Ziaja, K. \& Ekiert, H. 2009. Indole compounds in fruiting bodies of some selected Macromycetes species and in their mycelia cultured in vitro. Die Pharmazie, 64: 479-480.

Muszyńska, B., Sułkowska-Ziaja, K. \& Ekiert, H. 2011a. Indole compounds in fruiting bodies of some edible Basidiomycota species. Food Chemistry, 125: 1306-1308.

Muszyńska, B., Sułkowska-Ziaja, K. \& Ekiert, H. 2011b. Indole compounds in some culinarymedicinal higher basidiomycetes from Poland. International Journal of Medicinal Mushrooms, 13:449-454.

Muszyńska, B., Maślanka, A., Sułkowska-Ziaja, K. \& Ekiert H. 2011c. Analysis of indole compounds in Armillaria mellea fruiting bodies. Acta Poloniae Pharmaceutica - Drug Research, 68: 93-97.

Oddoux, L. (ed.). 1957. Recherches sur les mycéliums secondaires des Homobasidiés en culture pure. Imprimerie de Trevoux, Lyon.

Reczyński, W., Muszyńska, B., Opoka, W., Smalec, A. \& Sułkowska-Ziaja, K. 2013. Comparative study of metals accumulation in cultured in vitro mycelium and natural grown fruiting bodies of Boletus badius and Cantharellus 
cibarius. Biological Trace Element Research, 153: $355-362$.

Roberts, J. 2008. Vitamin $\mathrm{D}_{2}$ formation from postharvest UV-B treatment of mushrooms
(Agaricus bisporus) and retention during storage. Food Chemistry, 56: 4541-4544.

\section{Streszczenie}

Lecznicze i przeciwutleniające właściwości grzybów są doskonałym połączeniem, które stanowi o ich wartości dietetycznej i umożliwia korzystanie z nich zarówno, jako żywności jak i dodatku żywieniowego. Celem niniejszej pracy była analiza zawartości fizjologicznie aktywnych związków indolowych w mycelium z kultur in vitro Agaricus bisporus (pieczarka dwuzarodnikowa). L-tryptofan, egzogenny aminokwas i jego pochodne, takie jak np. 5-hydroksytryptofan, muszą być dostarczane z pokarmem w codziennej diecie. Związki te mają działanie przeciwdepresyjne, są bezpośrednimi prekursorami serotoniny, a w przeciwieństwie do niej przekraczają barierę krew mózg. Są też biogenetycznymi prekursorami innych związków indolowych, które pełnią funkcję neuroprzekaźników, co uzasadnia oznaczanie ich zawartości w grzybach jadalnych. Materiał do badań stanowiły owocniki A. bisporus pochodzenia komercyjnego. Z owocników A. bisporus wyprowadzono kultury in vitro na podłożu stałym Oddoux (1957). Eksperymentalne kultury in vitro prowadzono na płynnym, wytrząsanym podłożu Oddoux. Co dwa tygodnie prowadzenia kultur pasażowano je na świeżą pożywkę. Biomasę mrożono i suszono metodą liofilizacji. Otrzymaną biomasę z kultur in vitro analizowano jakościowo i ilościowo metodą HPLC na obecność niehalucynogennych związków indolowych.

Po raz pierwszy zidentyfikowane i ilościowo oznaczone zostały związki indolowe w kulturach in vitro Agaricus bisporus na płynnym podłożu wg Oddoux. Analiza wykazała, że ekstrakty metanolowe otrzymane z grzybni zawierają sześć związków indolowych: L -tryptofan, 5 - hydroksytryptofan, serotoninę, melatoninę, tryptaminę i 5-metylotryptamię. Zawartości poszczególnych składników w biomasie z kultur in vitro były zróżnicowane w zakresie od 0,01 do $21,33 \mathrm{mg} / 100 \mathrm{~g} \mathrm{~s}$. m. Dominującymi ilościowo związkami były: 5-hydroksytryptofan (12,50 mg/100 g s. m.), L-tryptofan $(14,00 \mathrm{mg} / 100 \mathrm{~g})$ i serotonina $(7,00 \mathrm{mg} / 100 \mathrm{~g})$. Całkowita zawartość związków indolowych w badanym materiale wynosiła 55,32 mg/100 g s. m. Biomasa z kultur in vitro badanego gatunku jest dobrym źródłem 5-hydroksytryptofanu i L- tryptofanu. Kultury in vitro $A$. bisporus mogą być wykorzystane jako model do badań nad akumulacją i metabolizmem związków indolowych. 